SCIENTIFIC RESEARCH 


\title{
NATIONAL MONITORING SYSTEM OF THE COUNTRY FOR HYDROMETEOROLOGICAL PHENOMENA
}

PhD Dariusz DRZEWIECKI

National Defence University, Warsaw, Poland

\begin{abstract}
In the publication, there is an analysis of the dangerous phenomena of weather - strong wind and ice accumulation. Two examples of the synoptic situation were placed with the wind as they made their analysis based on weather maps. At the end, a methodology for registering and information transfer about threats in regional networks is presented and a few chosen weather web portals in common use are selected.
\end{abstract}

Key words: meteorology, weather, strong wind, maps, ice accumulation, regional networks, web portals, keys to the encryption of weather information, meteorological telegram

\section{Introduction}

Depending on the type of the means of transport, the influence of the atmospheric phenomena on its functioning is different. Air transport is most sensitive to changes in weather conditions; however, violent and heavy snowfall, ice or a strong wind, can cause disruption to land transport. Huge falls of wet snow, ice and a strong wind can break overhead power lines, cut central heating and essential fuel deliveries to industry. 


\section{Elements and meteorological phenomena}

All of the time, diverse physical processes take place in the atmosphere, causing constant changes to its physical characteristics. The physical characteristics of the atmosphere include the elements and meteorological phenomena. The most important meteorological components are: the atmospheric pressure, the density and the humidity of air, the rainfall and the snow, the visibility and the direction of the wind. Storms, fogs, black ice, ice, turbulence, squall and strong wind are ranked among atmospheric phenomena. Elements and meteorological phenomena in determined situations can achieve extreme values which influence the functioning of land, sea and air transport and, hence, affect the safety of important departments of the national economy.

\section{Ice accumulation}

Freezing rain is ranked as very dangerous for transport it being cause by the freezing of over-cooled drops of water on surfaces in temperatures from $0{ }^{\circ} \mathrm{C}$. A heavy snowfall is also dangerous. It can reduce horizontal visibility even up to a few meters and obscure communication trails, and wet lying snow can cause power lines to break under its weight. The changeable character of the climate in Poland causes the so-called phenomenon of zero crossing which appears during the months of the cool season. The temperature within a few minutes falls from above zero to $[-1 \div-2]^{\circ} \mathrm{C}$ and then returns to plus. Sometimes such a situation can repeat itself several times a day. Local factors determining the microclimate of a particular place affects the course of this occurrence such as: mountainous area, exposed to the sun, type of infrastructure, local hot spot, character of bodies of water, rivers and the like. The dangerous phenomena of the weather is difficult to forecast locally. They are often the greatest threat to communication safety. In April 2008, during a strong wind, wet snow falls and freezing rain settled on trees, energy poles and overhead power lines. It caused the biggest energy disaster in the post-war history of Poland. It spread into Szczecin and part of Western Pomerania (fig. 1). Trains and trams were halted and school cancelled. Banks, 
shops and petrol stations were closed. Mobile phones went quiet. After a few hours, problems delivering running water and with sewage collection began.

A sweep of lower pressure caused a change in weather for two lowland centres (fig. 2 and 3). In the area of the North Sea, the system of weather fronts transferring a low-pressure system to the East warmed the cool and humid air mass, causing a great fall of snow and snow combined with rain and in the evening they swiftly froze.

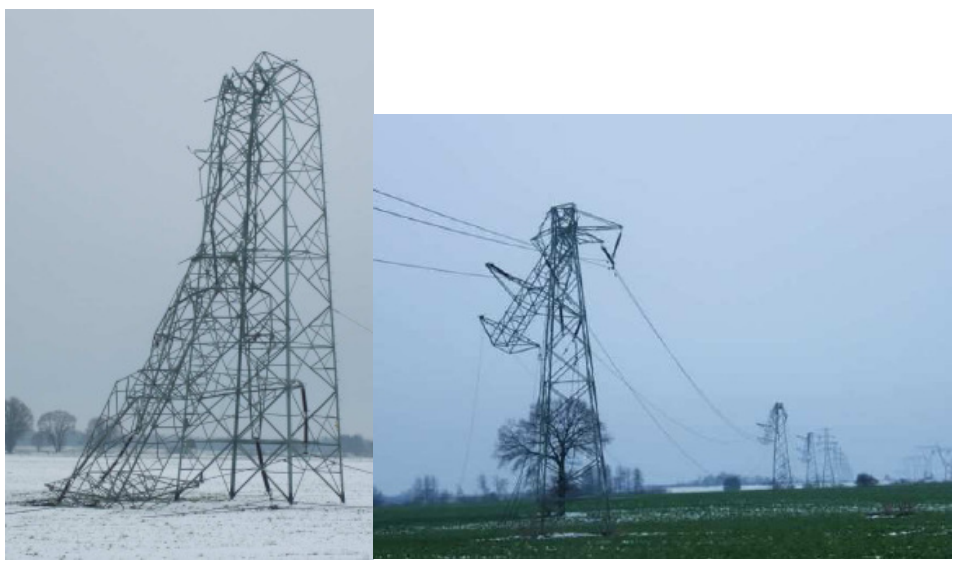

Source: /www.szczecin.eu/.

Fig. 1. Broken power lines in the area of Szczecin 07.04.2008

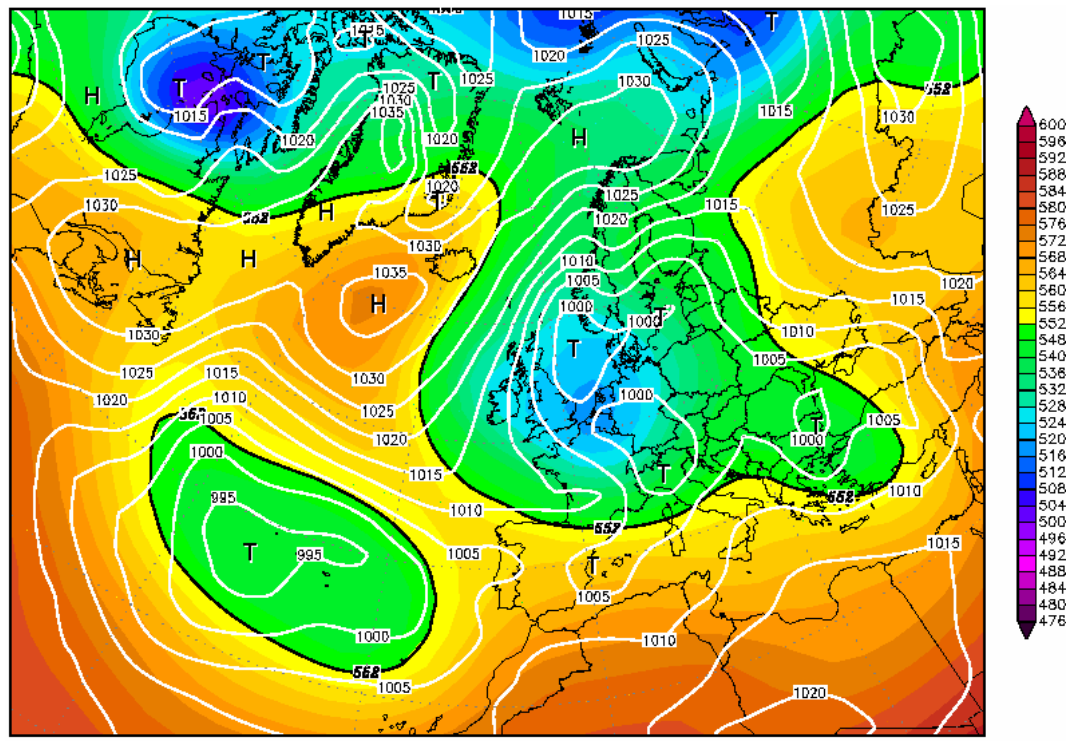

Source: http: / www.wetterzentrale.de/.

Fig. 2 Map 500 hPa with down-to-earth barometric field. Day 07.04.2008 00.00 UTC 

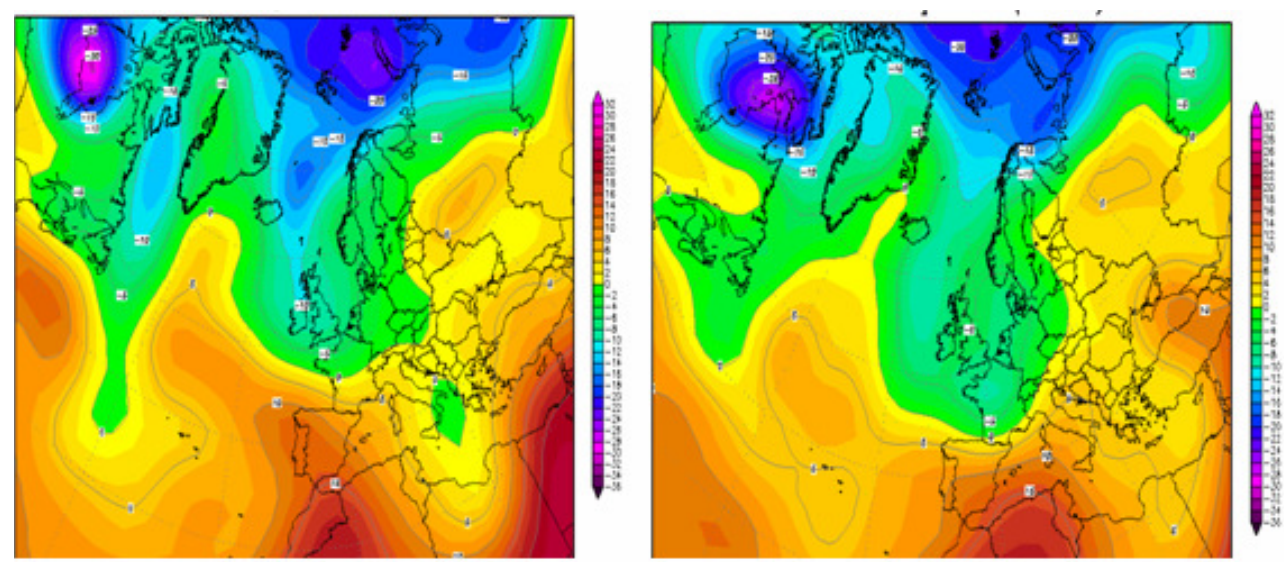

Source: http: / www.wetterzentrale.de/.

Fig. 3 Maps 850 hPa with temperature zone Days 06-07. 04.2008. 00.00 UTC

The problems were especially intense in places where there was a large amount of steam e.g. close to the Oder river and her overflow areas, causing the sedimentation of the „wet snow”, especially on power lines. As a consequence freezing layers accumulated on power lines and even broke them.

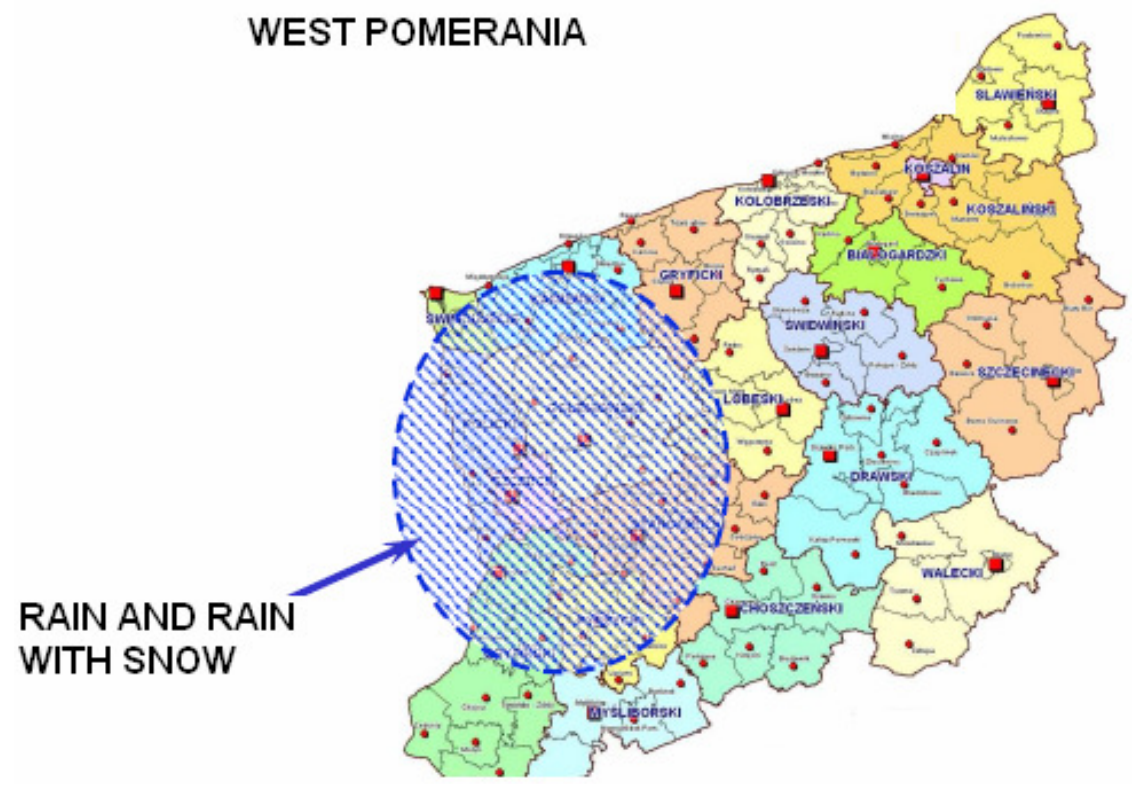

Source: /www.szczecin.eu/.

Fig. 4 Reach of falls in 07.04.2008 
A disaster of this scale can happen in every area of Poland and it could have the same or greater effect. In our climatic zone, weather situations causing energy breakdowns aren't rare (fig. 4). They often appear in the winter season and in early spring, when the air temperature is fluctuating around zero, while freezing falls of $t$ rain and wet snow occur. Let's suppose the weather conditions weren't only one of factors which led to the disaster in 2008. The disappointing warning system and the existing situation showed the bad technical condition of energy networks in our country. Abundant snowfalls in our region are most often connected with the appearance of cumuli on weather fronts in the winter season; however, falls of wet snow can appear late in autumn and in spring, when we are dealing with the overlap of different air mass, cool and humid from the north-west and warmer from the south. The air temperature is fluctuating around zero (fig. 3). Therefore, at that time, the probability of a failure of energy networks is greatest. On 6-7 April 2008, (see www.szczecin.eu) about 628,000 residents of the province were deprived of electricity including 330000 residents of Szczecin.

\section{In the city of Szczecin}

- the tram service didn't run,

- the system of the supply of thermal energy didn't function,

- sewage collection was hampered,

- the commercial network was out of order,

- banks and ATMs were out of order,

- work stopped in the Szczecin Shipyard and the "Gryfia" repair yard and the seaport Szczecin-Świnoujście,

- the activity of schools and nursery schools was limited,

- cash registers were out of order, petrol stations lost power and the Internet failed.

It is hoped that a similar disaster won't happen in this area in the future. Recently, information was published in a local newspaper in relation to the large-scale investment in Szczecin. The sea wind power stations in Bilfinger Szczecin want to build a factory in order to enable transport of big structures on Odra river by constructing, a power line under the river. 


\section{Hurricane wind}

Above the area of Poland, a hurricane wind is more and more often another particularly dangerous and registered occurrence (speed above $33 \mathrm{~m} / \mathrm{sec}$.).

Meteorological stations determine the wind by instruction IMGW, 1988,

„Horizontal air movement relative to the surface of the Earth. The wind is characterised by its direction and speed. Wind speed is the distance that can beat the air molecule at a specific time.

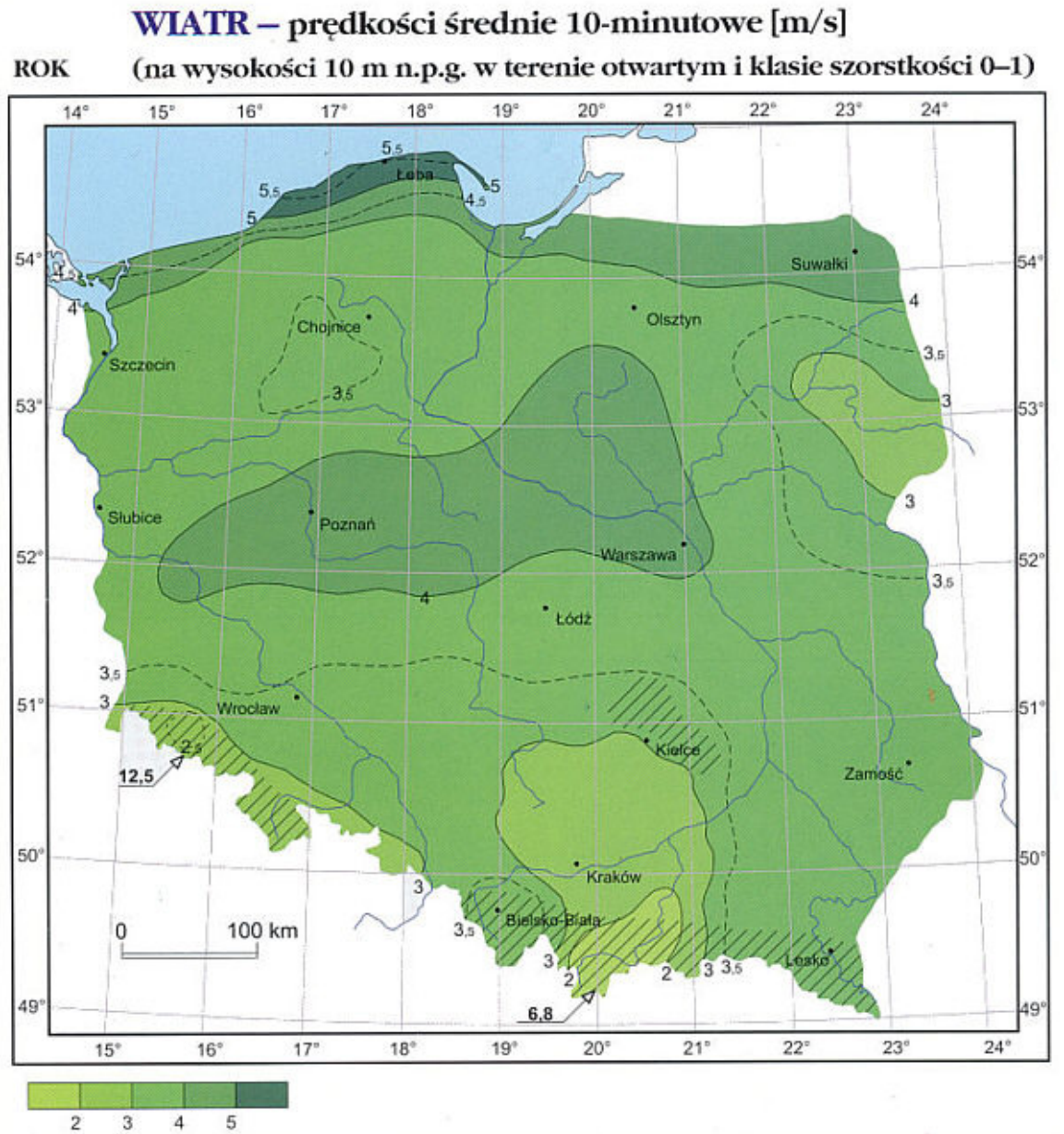

Source: Atlas of the Climate of Poland beneath the editorial office of Halina Lorenc, the Meteorological Office and of water management (IMGW). Warsaw 2005.

Fig. 5 Spatial schedule of the field of the wind in Poland 
Wind direction and speed determine the strength characterizing the pressure field: the strength differential pressure, centrifugal force and Coriolis force. Forces of friction also have an influence on wind speed and direction. Every obstacle disrupts the field of the wind. These include large scale obstacles e.g. mountain ridges, as well as those of a smaller scale of e.g. developing forests etc. Every obstacle draws aside the direction of the air current which must avoid them or sail above them. When the obstacle lie at right angles to the direction of the stream of air (e.g. mountains), in accordance with the law Bernoulli, air velocity increases over the top of them; however, in valleys and river troughs it decreases. Sailing around the obstacles, the wind speed decreases; however, it grows from the side. Behind the obstacle, the wind speed decreases and a "wind shadow" is created. The wind speed grows when air moves along the river bed becoming a narrow geographic zone, triggered by the thickening of the izolines. In the situation, when the terrain doesn't constitute the distinct disrupting factor, the directions of the wind in the ground atmospheric layer depend on direction and the speed of the motion of barometric arrangements. The temperate climate in which Poland is situated is characterised by the appearance of strong winds. Horizontal air movement of wind (on a global scale) is connected with the general circulation of the atmosphere; however, local wind (foehn wind, foehn) is determined by the weather situation. In Poland, we also see whirlwinds and water. Disintegration of the wind in Poland (excluding the highlands) appears in four sectors. High rates of speed have been recorded in the centre and the eastern part of the Baltic coast, from Mielno through Łeba to the Hel peninsula - $30 \mathrm{~km}$ deep into the land. It is possible to observe medium wind speeds in two areas.

The first area embraces the north part from Świnoujście in the west up to Suwałki. It spreads through this zone area from about $20 \mathrm{~km}$ deep into the central coastal land up to about $80 \mathrm{~km}$ in the East. The other area is in the heart of the country, from the central part of Greater Poland and north and west of Masovia. The smallest wind speeds have been recorded in Lesser Poland and in the area of Białowieża ( fig. 5). Wind develops completely differently in the mountains. Here it is determined by the geographical conditions. For example, southerlies dominate the Kasprowy peak and, additionally, a number of strong winds of 11-15 $\mathrm{m} / \mathrm{sec}$. and $>15 \mathrm{~m} / \mathrm{sec}$ have been noted. The maximum high rates of windspeed fall in winter. However, in the buried mountain valley, generally speaking a wind wasn't recorded about speeds above $11 \mathrm{~m} / \mathrm{sec}$ for years. (Drzewiecki D., 2001). 


\begin{tabular}{|c|c|c|c|c|c|c|c|c|c|c|c|c|}
\hline \multirow{2}{*}{ WIND } & \multicolumn{12}{|c|}{ MONTH } \\
\hline & I & II & III & IV & v & VI & VII & VIII & IX & $\mathrm{x}$ & $\mathrm{XI}$ & XII \\
\hline \multirow{2}{*}{\multicolumn{13}{|c|}{$\begin{array}{l}\text { FRONT MASS } \\
\text { TYPE }\end{array}$}} \\
\hline & & & & & & & & & & & & \\
\hline \multicolumn{13}{|l|}{ FEN TYPE } \\
\hline & & & & & & & & & & & & \\
\hline LESS SCALE & & & & & & & & & & & & \\
\hline WHIRL & & & & & & & & & & & & \\
\hline
\end{tabular}

FREQUENCY OF THE WIND

HIGHEST

HIGHER

LOW

LOWEST

Source: Study - Government Centre of the Safety, Warsaw 2013.

Fig. 6 Periods when disastrous wind appeared in Poland and the appearance of whirlwinds in Poland in 2000-2008 according to European Severe Weather Database data

The annual seasonal character of disastrous winds in Poland is shown in (fig. 6). The wind associated with the migration of cyclone whirlpools most often appears in months of the winter season (often) and in early spring (March) and autumn (November). The least disastrous winds associated with whirlpools come in the summer season (June, July, August - less often). The spring and autumn seasons are characterised by the changeable appearance of disastrous winds with the tendency decreasing towards months with higher average temperatures of air.

Winds of the foehn type which have a different character are shown (the foehn wind or the Sudeten foehn). These frequently fall in the cool/cold? months (November, December, January), with their tendency decreasing from February to April - becoming further restrained from May to September.

Classification of degrees of threats of dangerous meteorological phenomena. Wind with high rates of speed (IMGW): 
1 Degree of threat:

Vśr $>15 \mathrm{~m} / \mathrm{sec}$. or $\mathrm{V}>20 \mathrm{~m} / \mathrm{sec}$.

Vśr - the medium wind speed

V -. Wind speed the lowest level - yellow colour

Damaging buildings, roofs; damage to tree trunks, breaking branches and trees; impeding communication.

Need for carefulness, to keep up with announcements and weather developments.

2 Degree of threat:

Vśr $>20 \mathrm{~m} / \mathrm{sec}$. or $\mathrm{V}>25 \mathrm{~m} / \mathrm{sec}$.

Vśr - the medium wind speed

V. Wind speed the higher level - orange colour

Damaging buildings, roofs; breaking and uprooting trees; hampering communication; damaging overhead power lines.

Need for carefulness, to keep up with announcements and weather developments.

3 Degree of threat:

Vśr $>25 \mathrm{~m} / \mathrm{sec}$. or $\mathrm{V}>35 \mathrm{~m} / \mathrm{sec}$.

Vśr Wind speed the highest level - red colour

Damage tobuildings, breaking roofs; damage to overhead power lines; great damage to tree trunks; considerable impediments to communication; threat to life.

Above Poland on 18 Jan 2007, a series of low-pressure systems moving from west to east along with a zone of quickly moving weather fronts shaped the weather (fig. 7). On that day, Poland was under the influence of a deep trough from the centre to the North Sea, where the drop in pressure rarely reached $965 \mathrm{hPa}$. 
On the satellite image with the TB 500 field from 18 Jan 2007 (fig. 8) we can see thick Nimbostratus and billowy layered clouds covering the west and centre part of Europe. Only in the area of the Black Sea and the eastern part of the Mediterranean Sea can we see an area of brighter spells, triggered by the zone of raised pressure embracing the north part of Africa and the Mediterranean Sea.

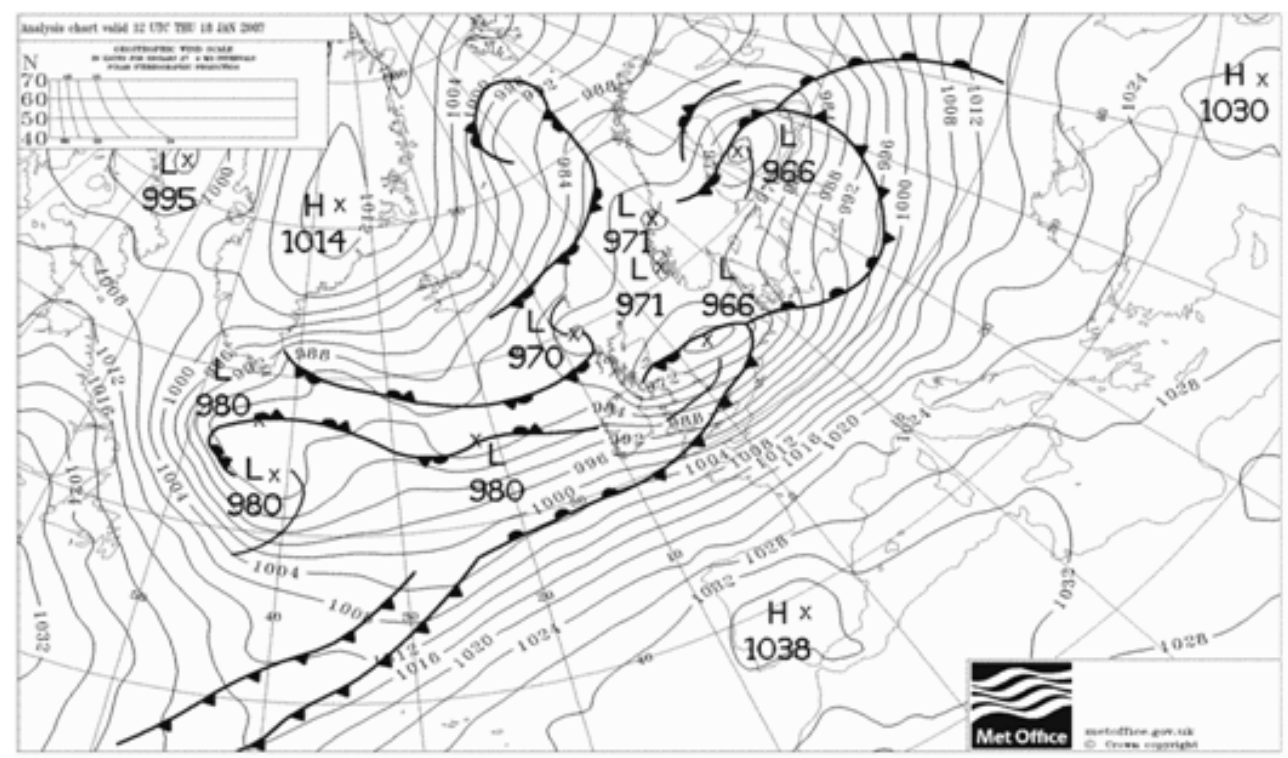

Source: http: / www.wetterzentrale.de/.

Fig. 7 Down-to-earth synoptic situation from 12.00 UTC 18.01.2007

Big thickening contour lines created a belt about $3000 \mathrm{~km}$ wide, spreading through Great Britain and the central part of Europe and further to the East, spreading to the north part of the Mediterranean coast along with the massif of the Alps. This is characteristic for high-velocity wind, at its maximum on 18 Jan 007 above Denmark and the northern territories of Germany and Poland. 


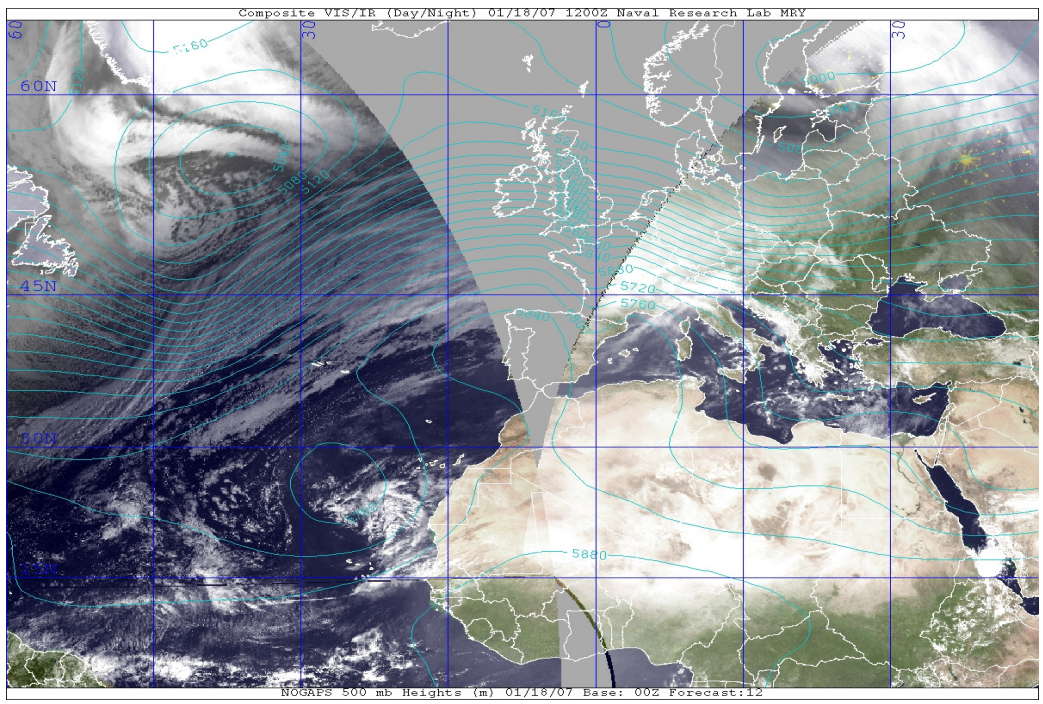

Source: http: / www.wetterzentrale.de/.

Fig. 8. TB 500 Analysis 12.00 UTC 18.01.2007

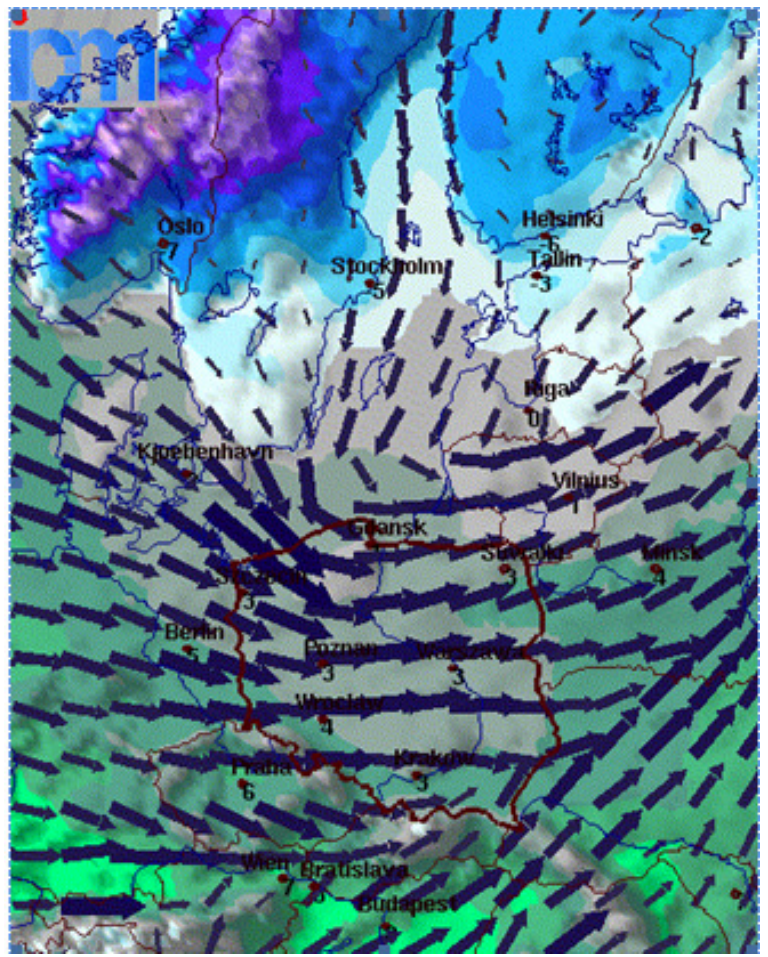

Source: http: / meteo.icm.edu.pl/.

Fig. 9. the Speed and the direction of the wind 00.00 UTC 19.01.2007 
The zone of maximum wind speeds transferred the following day into the area of north-western and western Poland, gradually embracing the entire country (see fig. 9).

\section{Chosen keys for the encryption of results of down-to-earth meteorological observations}

Hydrometeorologicalservice, both civiland military, provideshydrometeorological cover for society and sectors of the national economy. The work involves measuring meteorological stations acquired from the network and servicemen testing meteorological systems from air force bases). Observation and measurements are performed within specified time limits, in the form encrypted of telegrams, directed into interested cells and into the international exchange network.

The encryption of the results of measurements and hydrometeorological observation isn't a way of keeping this data secret, on the contrary, streamlining them is aimed at world circulation; therefore, the keys applied to the encryption of weather information are universal and intelligible worldwide. Observation at synoptic targets is performed worldwide on the same dates, established according to the UTM universal time (Universal Time Coordination). Established dates of main and indirect observation in the international exchange are 00.00, 03.00, $06.00,09.00,12.00,15.00,18.00,21.00$, in the domestic exchange - hourly, always about half an hour at the meteorological service of the air forces. Results of all measurements and observation are sent regularly and additionally documented in daily newspapers.

SYNOP - code with the help of which meteorological observations from meteorological stations worldwide are coded.

The SYNOP telegram includes:

- the speed and the direction of the wind ( lifts),

- visibility,

- current weather conditions (present weather),

- more previous weather conditions (recent weather),

- clouds including the type of clouds determined (sky condition), 
- air temperature,

- atmospheric pressure.

The general form of the SYNOP key (below) is a set of letters and digits, divided in groups, consisting of five signs of which identifiable components and weather phenomena are characteristic.

\section{AAXX YYGGiw}

IIiii $i_{R} i_{x} h V V$ Nddff $1 s_{n}$ TTT 2s ${ }_{n}$ TdTdTd 3PoPoPoPo 4PPPP 5aPPP 6RRRtR 7wwW1W2 8NhCLCMCH

Explaining the key:

AAXX - symbol of the SYNOP telegram

YYGGi $_{\mathbf{w}}$ - day of month (YY), hour of performing observation according to the UTM time (GG), gauge of the wind (of great sallows);

IIiii - number of the area (II), number of a meteorological station (iii);

$\mathbf{i} \mathbf{R}_{i} \mathbf{X}_{\mathbf{h}} \mathbf{V V}$ - indicator of the rain group $\left(i_{R}\right)$, rate of the type of the station $\left(i_{X}\right)$, height of the base of low clouds (h), the visibility in the horizontal direction (VV);

Nddff - size of general clouds $(\mathrm{N})$, the direction of the wind bottom (dd), the wind speed bottom (ff);

Numbered groups from 1 to 8

$1 \mathbf{s}_{\mathbf{n}}$ TTT - numerical sign (1), sign of the temperature (s), the air temperature - to tenth of step (TTT);

$2 \mathbf{s}_{\mathbf{n}}$ TdTdTd - numerical sign (2), sign of the temperature (s), the temperature of the dew point (TdTdTd);

3PoPoPoPo - numerical sign (3), atmospheric pressure on the level of the station (PoPoPoPo);

4PPPP - numerical sign (4), atmospheric pressure reduced to the sea level (PPPP); 
5aPPP - numerical sign (5), symbol of the tendency of the pressure (a), the magnitude of the tendency of the pressure on the level of the station, in the period of three hours preceding observation (PPP);

6RRRtR - numerical sign (6), level of the fall in the run-up time of observation (RRR), duration of the period as which the level of the fall is passing itself off (tR);

7wwW1W2 - numerical sign (7), current weather given by non-automated stations (ww), last weather given by non-automated stations (W1W2);

$\mathbf{8 N h C} C_{L} C_{M} C_{H}$ - numerical sign (8), size of clouds through all clouds (Nh), size of clouds through clouds of the low, average, high floor $\left(\mathrm{C}_{\mathrm{L}} \mathrm{C}_{\mathrm{M}} \mathrm{C}_{\mathrm{H}}\right)$.

Real form of the encrypted SYNOP telegram (below):

\section{AAXX 06181}

\section{$12375315255160510107201013998240115551116 / / / / 7105288800=$}

AAXX - symbol of the SYNOP telegram,

06181 - the sixth day of month (06), the eighteenth UTM hour (18), the wind speed in the $\mathrm{m} / \mathrm{sec}$. (1);

12375 - Poland (12), Warsaw (375);

31525 - No. 6 is lacking the group (3), non-automated station - the seventh group inckuded (1), height of the base of low clouds $600-1000 \mathrm{~m}$ (5), visibility of 2500 $\mathrm{m}(25)$,

51605 - general clouds $5 / 8$ (5), the direction of the wind $155^{\circ}-164^{\circ}(16)$, speed of $5 \mathrm{~m} / \mathrm{sec}$. (5);

10107 - positive temperature (0), $10.7^{\circ} \mathrm{C}(107)$,

20101 - temperature of the dew point positive (0), $10.1{ }^{\circ} \mathrm{C}(101)$,

39982 - atmospheric pressure on the level of the station $998.2 \mathrm{hPa}$ (9982),

40115 - atmospheric pressure reduced to the sea level $1011.5 \mathrm{hPa}(0115)$,

55111 - drop of the pressure then height about $11.1 \mathrm{hPa}(111)$, 
$\mathbf{6} /$ / / / - a rain group is missing (however, in the key, in order to avoid the mistake of the group without data. However, they will leave in the form / / / (/ / /),

71052 - mist (10), drizzle (5), clouds covered skies more than half(2);

88700 - size of clouds through all clouds 8 / 8 (8), is driving clouds of the low Stratus floor fractus (7), lack of clouds of the average floor (0), lack of clouds of the high floor (0).

METAR - format (coded) of report on the weather used in aeronautical meteorology and a weather forecast. METAR is an acronym of METeorological Aerodrome Contango. They are usually being sent to METAR hourly by civilian stations; however, military stations are sending the METAR key every 30 minutes. The typical METAR contains information about the temperature, the pressure, the temperature of the dew point, the speed and the direction of the wind, fall, cloud cover, height of the cloud base, visibility, and also other information (e.g. state of runways).

The METAR telegram has the form (such symbolism as in SYNOP)

\section{CCCC YYGGggZ dddff of VVVV WW NNNhhh TT/TdTd PhPhPhPh}

Where:

- CCCC - marking the airport with the code ICAO

- YYGGggZ - the day of month and the time of observation in hours and minutes (UTC)

- dddff - wind direction and the speed

- VVVV - visibility in metres

- WW - atmospheric phenomena

- NNN - size of clouds (indicating clouds)

- hhh - height of the cloud base

- TT - temperature

- TdTd - temperature of the dew point

- PhPhPhPh - atmospheric pressure

Moreover, in the international system of the information transfer, weather telegrams are also used: 
STORM - telegram warning, information about coming dangerous phenomenon closing in

AVIO - verbal sign for telegrams, information about the disappearance or experiencing the occurrence

SHIP - telegram for the encryption of results of observation of weather from ships

TEMP - telegram for the encryption of results of measurements of the survey

\section{Chosen web portals and geoportals of weather}

There are several web portals presenting dangerous weather phenomena. Here are some of them- the most widely used in practice. The following shows European geoportals- examples: European Base of Extreme Phenomena ( fig. 10); Geoportal IMGW ( fig. 11); web portal - ICM (fig. 12, 13); geoportal Wetterzentrale German ( fig. 14,15,16); geoportal Wetter24 German ( fig. 17, 18).

\section{EUROPEAN BASE OF EXTREME PHENOMENA}

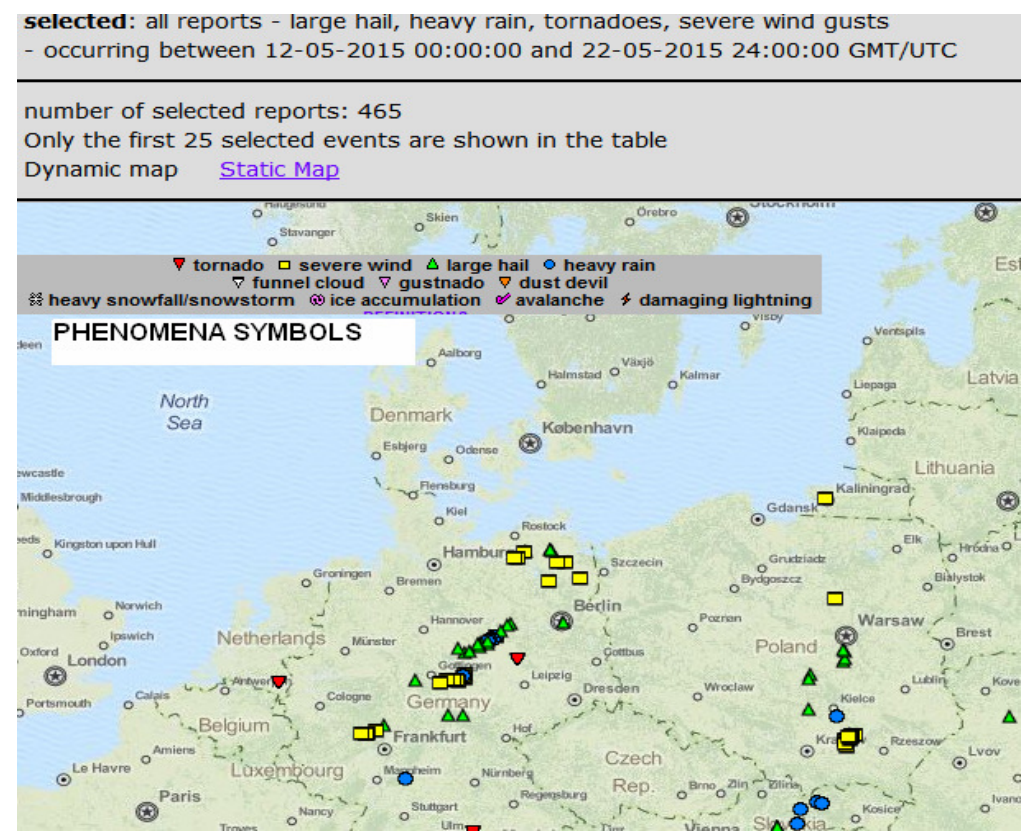

Source: http://www.eswd.eu/.

Fig. 10. European base of extreme phenomena (time period chosen for example of registered phenomena between 12.05 and 22.05.2015) 
GEOPORTAL IMGW Aviation (the Meteorological Office and of water management)

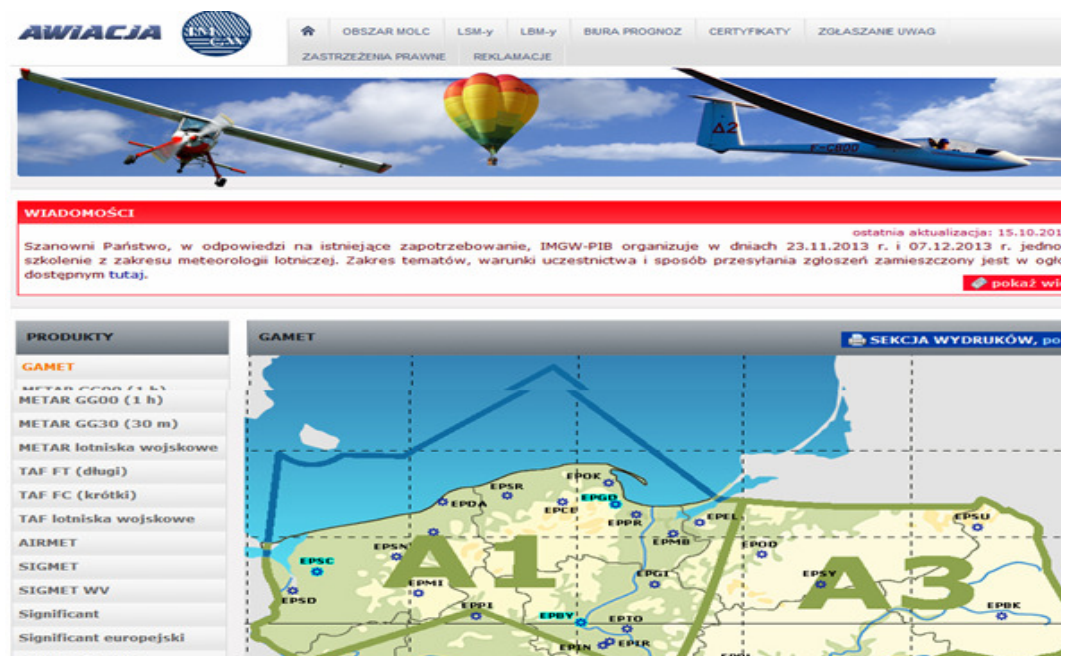

Fig. 11. Aviation - geoportal for pilots and followers of aviation (IMGW - The Meteorological Office and Water Management)

WEB PORTAL - ICM (Interdisciplinary Centre of the Mathematical Modelling) at the Warsaw University

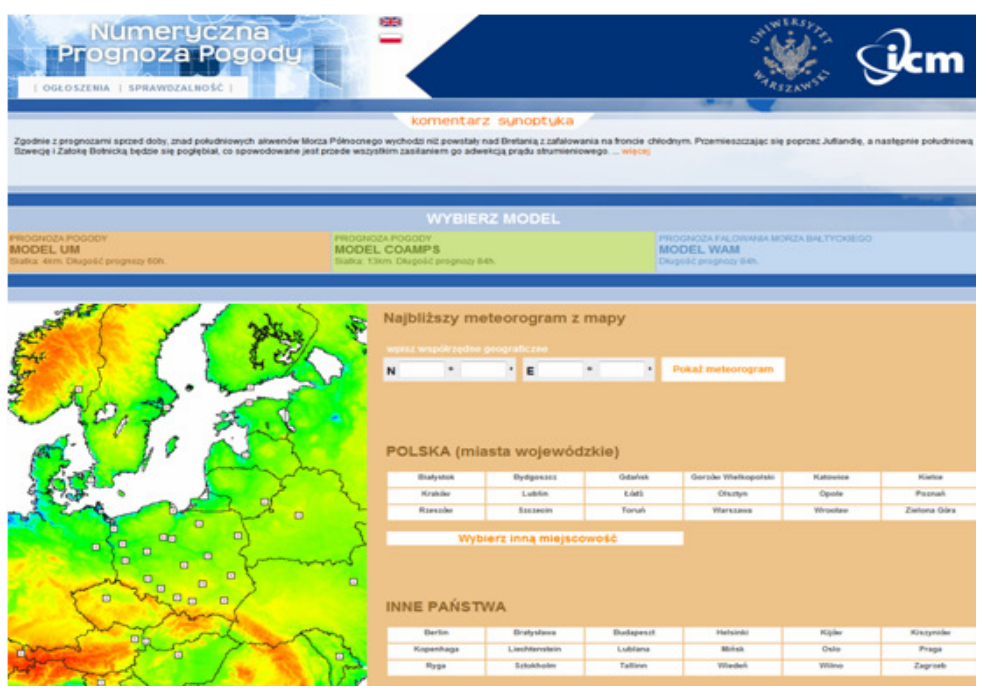

Fig. 12. Geoportal ICM (Interdisciplinary Centre of the Mathematical Modelling) at the Warsaw University. With the forecast of elements and phenomena of the weather for the chosen sites in Poland and in chosen states 

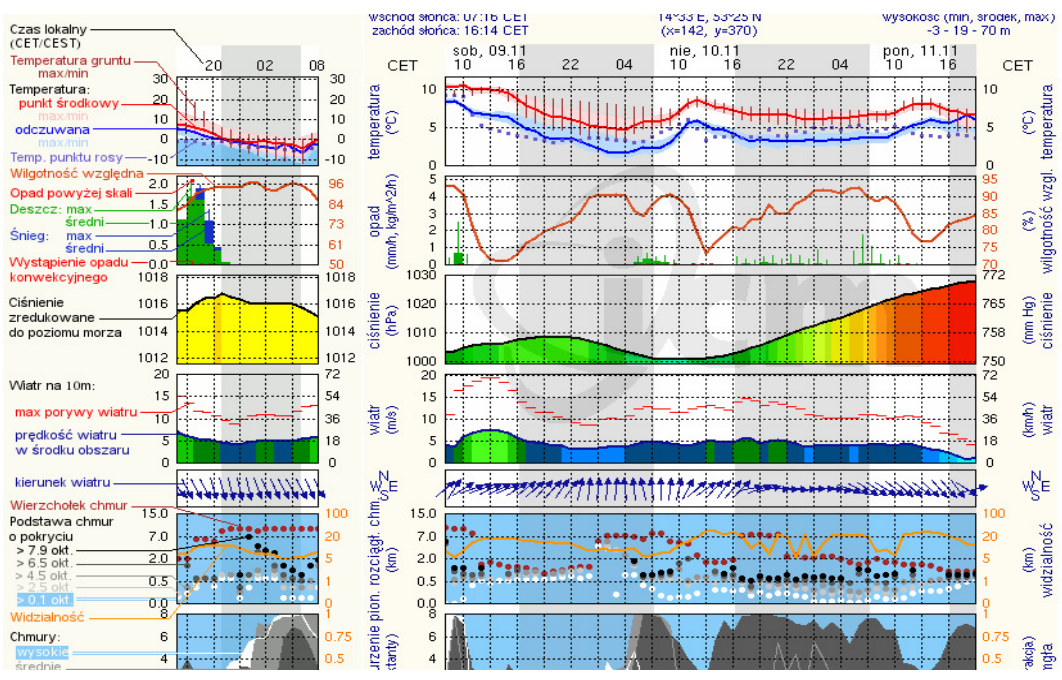

Fig. 13. Geoportal ICM (Interdisciplinary Centre of the Mathematical Modelling) at the Warsaw University, with the forecast of elements and phenomena of the weather for the chosen sites in Poland and in chosen states - example of depicting chosen meteorological elements and forecasting their course in time

\section{GEOPORTAL WETTERZENTRALE GERMAN}

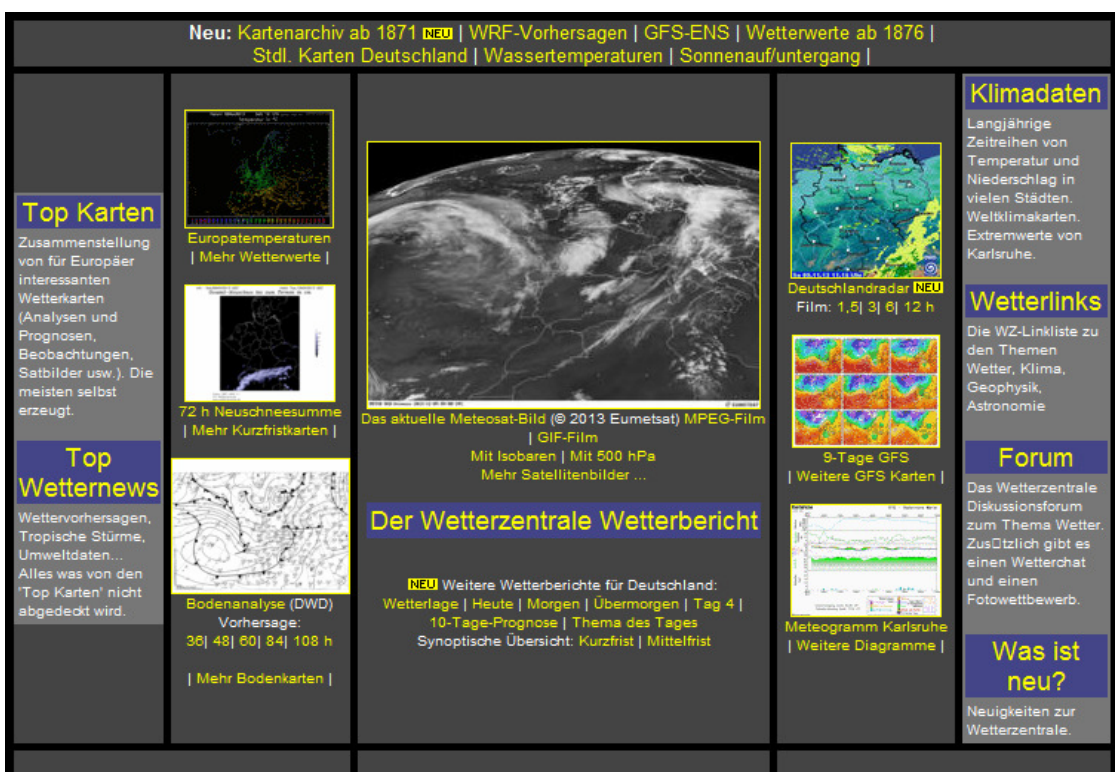

Fig. 14. Geoportal wetterzentrale.de German - offers a set of maps and presents analyses of current synoptic situations in the region and offers a set of climatic archival data 
Init : Mon, 18Nov2013 $12 Z$ Valid: Tue, 19 NOV2013 $12 Z$ $500 \mathrm{hPa}$ Geopot.(gpdm), $T(\mathrm{C})$ und Bodendr. (hPa)

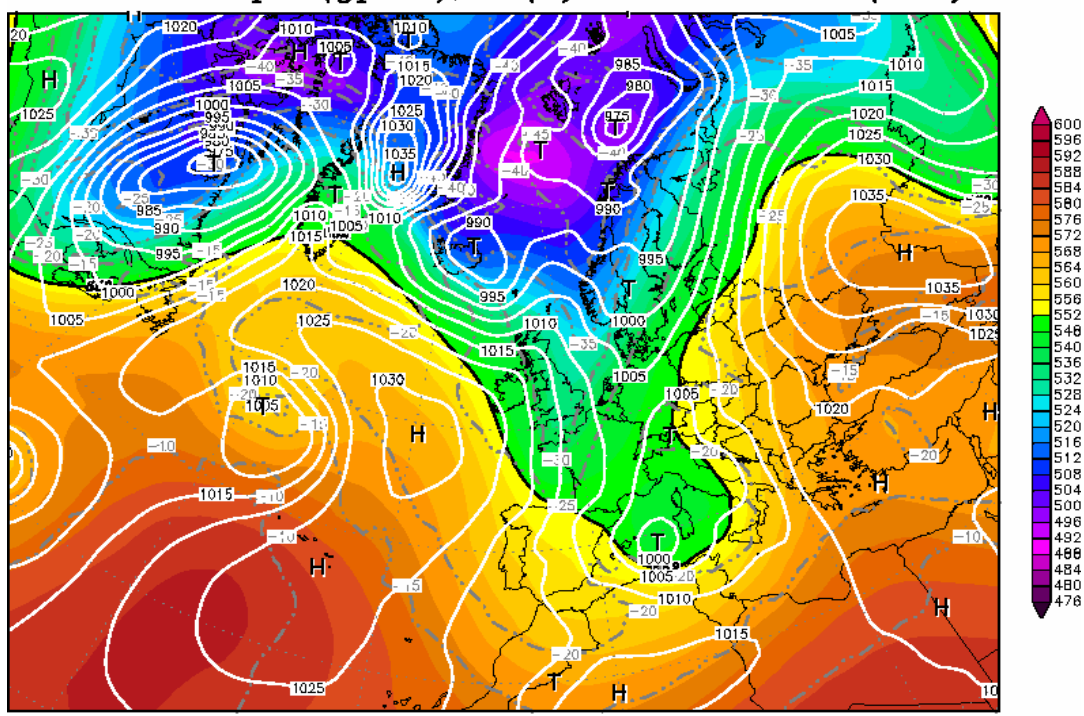

Daten: GFS-Modell des amerikanischen wetterdienstes C) Wetterzentrale

www.wetterzentrale.de

Fig. 15. Geoportal wetterzentrale.de German - example depicting field $500 \mathrm{hPa}$ with down-to-earth barometric field

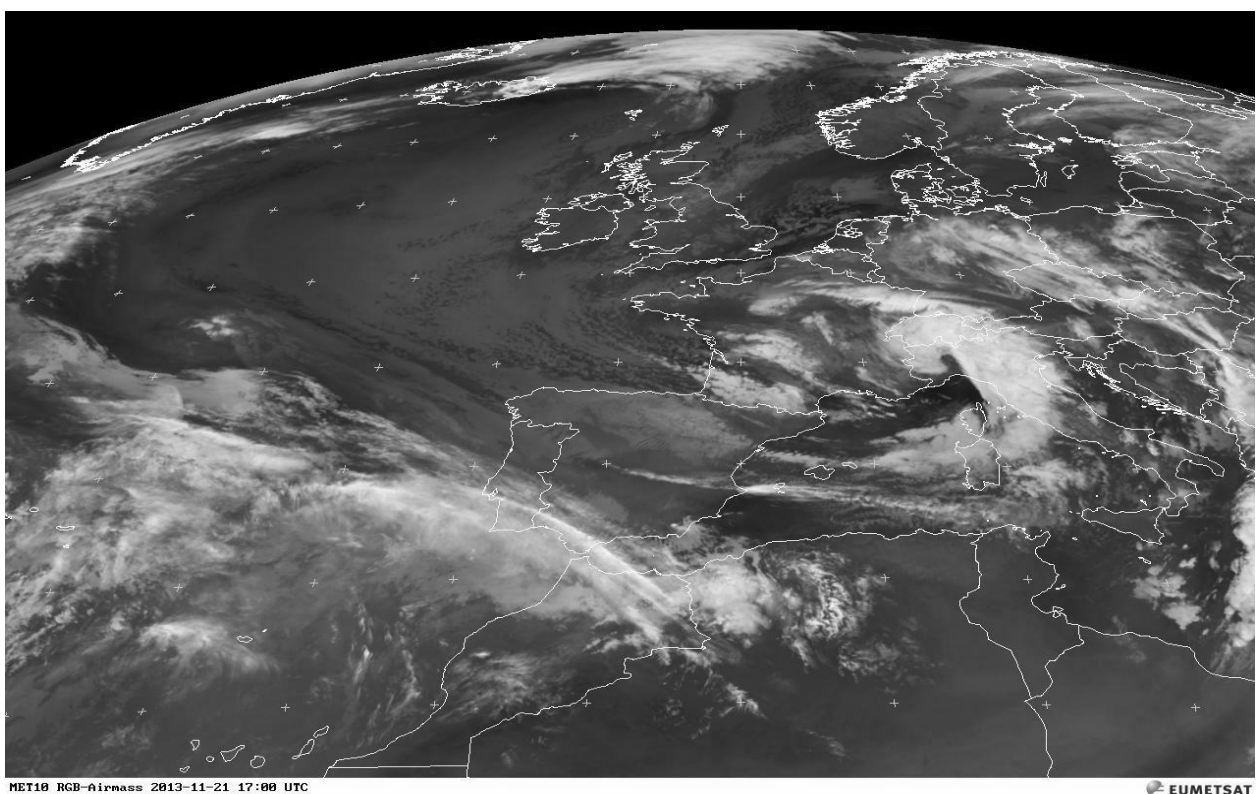

Fig. 16. Geoportal wetterzentrale.de German - satellite image from the EUMETSAT system - projection in the infrared (IR), from the hour 17.00 UTM time 
GEOPORTAL WETTER24 GERMAN

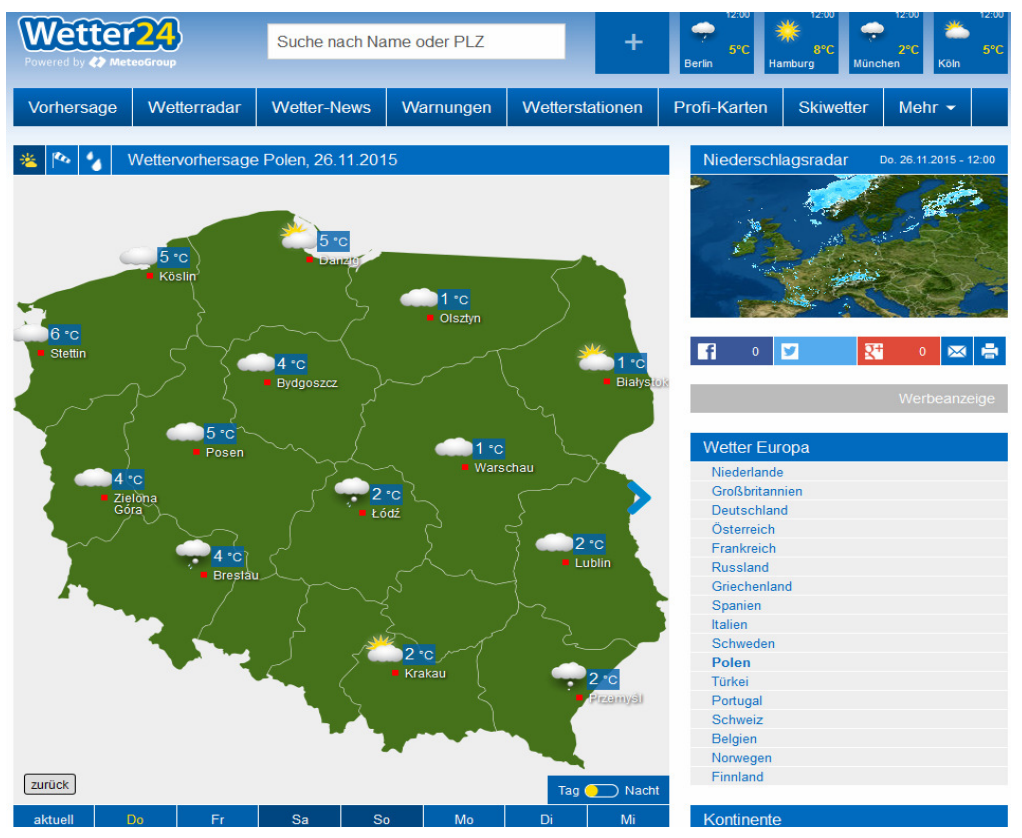

Source: http://www.wetter24.de/vorhersage/karte/europa/polen/.

Fig. 17. Geoportal Wetter24. The scope of data includes all European countries. Model page presenting meteorological conditions in chosen Polish cities

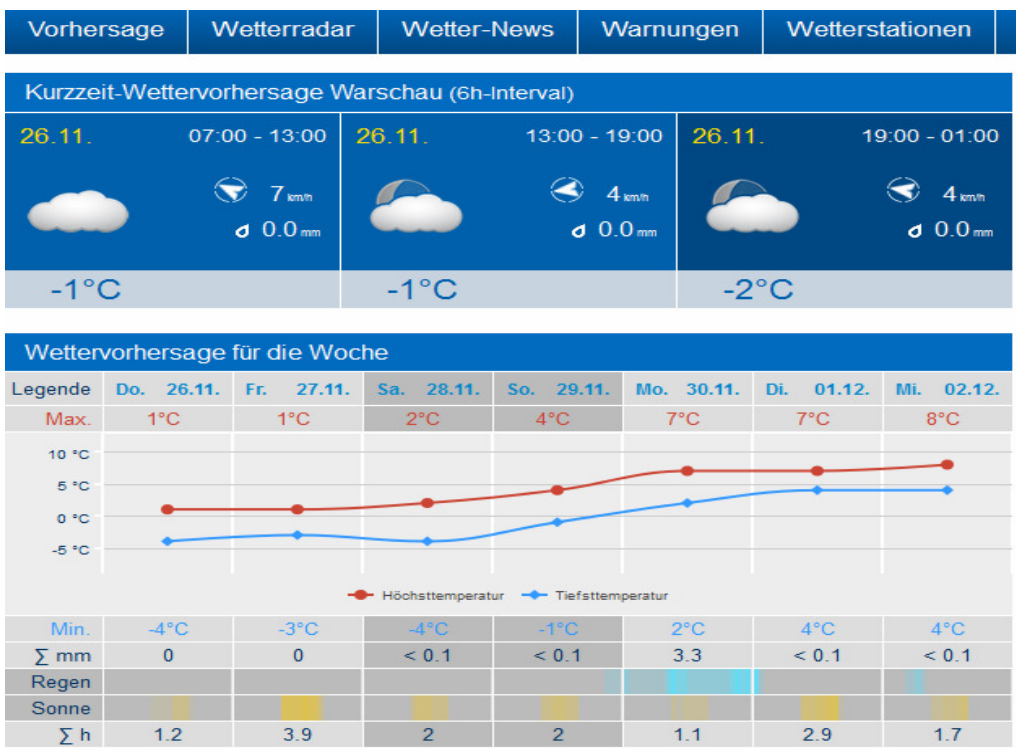

Fig. 18. Geoportal Wetter24. Example of the presentation of the seven-day-old forecast of the maximum air temperature in Warsaw 
ISOK system ( IT System of the Country's Protection against extreme hazards ).

The concept assumes construction of the ISOK system that the main data exchange between components of the system will take place via services in the SOA structure (service oriented architecture). Its functions are quickly adapted to changeable requirements and will enable construction of the system for users. The architecture of the system is publishes spatial data on the map server to WMS standards (Web of Service Maps) and WFS (Feature Service Web). Thanks to such a solution, the published data can be easily acquired by the any part of the architecture and interested users. The institutions responsible for the town-and-country planning will also be recipients of the results of the project and able to plan for protection against floods. Above all, these are the regional management boards of water management, responsible for the safeguard of areas threatened with flooding against developing them in a way that hampers protection. However, the overlords of communes and marshals of provinces are responsible for town-and-country planning. Taking project results into account will be their duty (flood hazard maps and flood risk maps) in land use plans for communes and provinces.

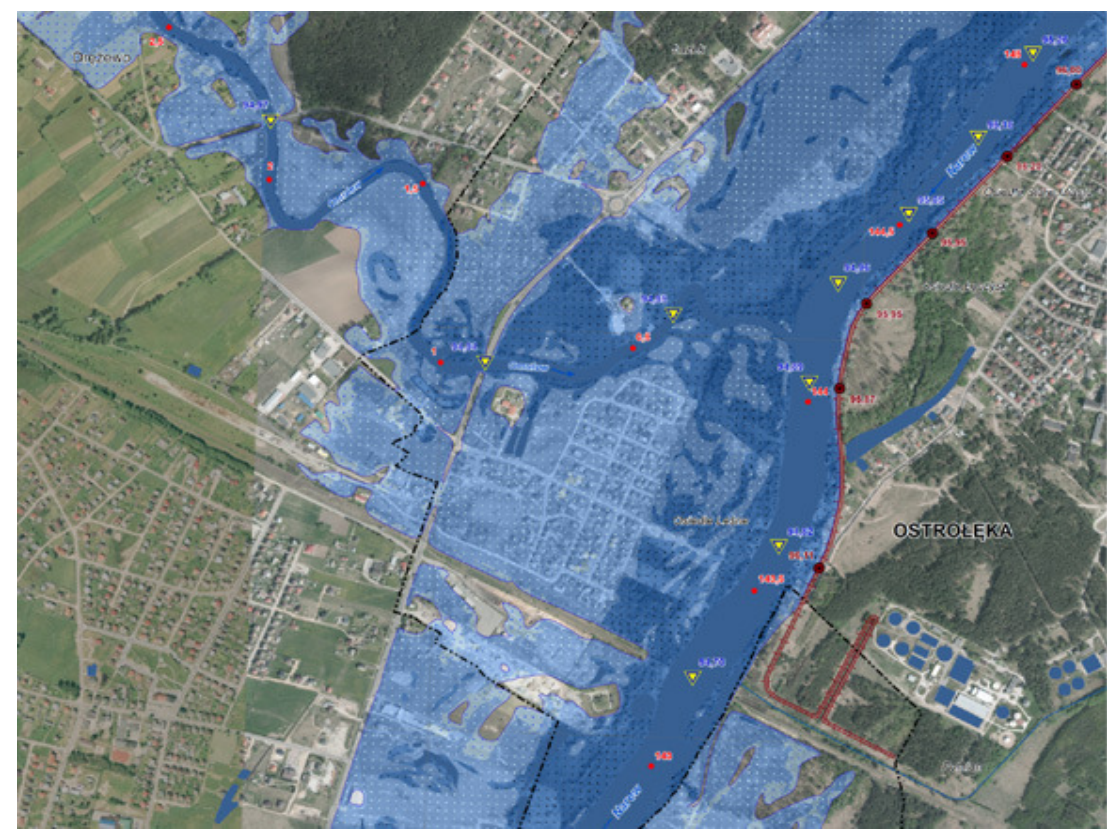

Source: (http://isok.imgw.pl/produkty-projektu-isok/platforma-informatyczna-isok/).

\section{Fig. 19. flood hazard map presented in the ISOK system}

Flood hazard maps show the area over which water will pour or rivers swell. 
Also, responsible institutions will be the recipients of ISOK products in accordance with the act on crisis management, behind the prevention for contingencies, preparing planned activities and taking control of them and reacting in the event of their withdrawal (fig. 19).

In particular, this means local centres of crisis management and other units of the government and self-government administration on a regional and local national level, dealing with protection issues before floods and other threats and reacting critically to them. Computer terminations will improve the abilities of the flood and critical management.

Access to complete and reliable information about possible natural and technological hazards is also essential for enterprises planning the completion of investment undertakings. The ISOK system flood hazard maps and flood risk maps are currently being made available. As part of task 8 , maps of meteorological threats will be drawn up: thermal, intense precipitations, strong wind, fog, ice accumulation, hailstorms, and snowfall

\section{The Useful Websites Concerning the Subject Matter of Hydrometeorological Threats}

http://unfccc.int/2860.php - page of the General Convention of Nations united on climate change;

http://www.ipcc.ch/ - side of the Intergovernmental Team for climate change (IPCC), whose reports judge climate change, including the fourth report, technical documents and special reports prepared by IPCC on;

http://unfccc.int/2860.php - page of the General Convention of Nations united on climate change;

http://www.ipcc.ch/ - side of the Intergovernmental Team for climate change (IPCC), whose reports judge climate change, including the fourth report, technical and special reports prepared by IPCC;

http://mos.gov.pl/ - side of the Ministry of the Environment; 
http://en.cop15.dk/ - Danish side of 15 sessions of the Conference of UNFCCC - COP15;

http://www.wmo.int - side of the World Meteorological Organisation;

http://www.imgw.pl/index.php - side of the Meteorological Office and water management;

http://www.ecmwf.int/ - side of the European Centre of medium-term forecasts (European Centre for Medium-Range Weather Forecasts - ECMWF);

http://www.ucar.edu/ - side of the Nationalist Centre of Atmospheric examinations (National Center for Atmospheric Research);

http://severe.worldweather.org/ - WMO service presenting warnings against sudden weather phenomena;

http://wwf.pl/projekty/klimat_energia.php - Polish page WWF concerning issues of climate change;

http://www.greenpeace.org/poland/kampanie/zmianaklimatu - Polish Greenpeace concerning issues of climate change;

http://www.zmianyklimatu.pl/ - portal devoted to the subject matter of climate change;

\section{Assessment of Chosen Systems Used in the Process of Warning Against Dangerous Occurrences of Weather}

New systems of warning about dangerous phenomena of the weather in the EU determine the availability of financial resources. This is an indicator of progress, partly modernised and supplemented with new devices, area radar system covering the entirety of Poland. An ISOK Computer System for Cover of the Country is next, for big money.-. It is praised by IMGW authorities and the system's authors and stirs up controversy amongst remaining users. A warning system can be the next example in Masuria where there was a violent storm in 2007 and a recordbreaking wind speed was noted in Mikołajki. In this case, stipulations formulated 
by yachtsmen as for its effectiveness have appeared. They don't concern the technical side of its functioning. Its problem is not always correctly interpreting received weather warnings. As a matter of fact, experience and human reason can not replace even a high technology.

\section{Conclusions and Closing Remarks}

The effects of a hurricane strength wind can spread through a province, one or a few districts, or in the case of a small scale wind - village Broken power lines are ranked among the most frequent losses and breaks of electricity supplies (broken electric traction on trains, malfunctioning of industrial plants with the threat of releasing hazardous substances into the environment), roads blocked by broken trees and branches, salt water forced into outlets of so-called river backwaters (a frequent occurrence in the Pomeranian bay and the lower reaches of the Oder), the rise of the water level and threat of flood, mass damage to the structure of halls and buildings, victims amongst the population as a result of crushing by trees or being damaged by elements of the infrastructure and masonry, and farming losses. In basins, ships are tied-up from unloading goods in seaports and inland, with the higher probability of shipwrecks sometimes impossible rescue operations.

The winter of 2006/2007 was the warmest since 1880 , since regular meteorological observations began - according to calculations of the federal Domestic Agency for Oceans and the Atmosphere (NOAA). The published NOAA report also states that the warming up of the entire planet is an indisputable phenomenon. The 10 warmest winters recorded in meteorological chronicles followed 1995. Every 10 years, the average temperature is rising about 1 / 5th. Global warming affects the height of the number and dynamics of the course extreme weather phenomena including hurricane winds; therefore, we will more and more often be exposed to the influence of these phenomena. In the specialist literature, it is possible to find a number of forecasting methods of dangerous weather phenomena. Unfortunately, there is a lack of scientific study concerning the adaptation of these methods to specific weather conditions, especially on the local scale. It is a pity that civilian research centres are concentrating on climatic analyses; however, the research on meteorological phenomena, especially from this position, is limiting the weather forecaster to theoretical deliberations. 


\section{Bibliography}

1. Drzewiecki D., 2001 - Geneza i dynamika wybranych zjawisk pogody niebezpiecznych dla lotnictwa (na przykładzie zachodniej części dorzecza górnej Wisły), praca doktorska, Uniwersytet Śląski, Wydział Nauk o Ziemi, Sosnowiec.

2. Barry R.G., 1981, Mountain weather and climate, Methuen, London and New York.

3. Barry R.G., Perry A.H., 1973, Synoptic climatology. Methods and applications. London

4. Burroughs W.J. 1991, Watching the world's weather. Cambridge University Press, Cambridge.

5. Drzewiecki D., Chaładyniak D., 2000, Satellite images acquisition from the Internet for military meteorologists educating. IV International Symposium on Military Meteorlogy, Hydro-meteorological support of allied forces and PfP member's tasks realization, Malbork Poland 26- 28 September 2000, materiały konferencyjne, s. 69- 76.

6. Chaładyniak D., Drzewiecki D., 2001, Application of GIRD data and satellite images investigation of frontolysis process. Uniwersytet Gdański, Rocznik fizycznogeograficzny, tom VI 2001, Zastosowanie danych girdowych w klimatologii i hydrologii, s. $51-5$

7. Drzewiecki D., 2003, Winds frequency in the strong different form of the ground. V International Symposium on Military Meteorology, Metoc Services' Tasks in NATO Operations, Missions and Exercises, Poznań Poland 1 - 3 October 2003, s. 67-69

8. Drzewiecki D., 2005, Problematyka przetwarzania danych klimatycznych. Zeszyty Naukowe Akademii Obrony Narodowej Nr 1(58)A, Warszawa 2005, s.185-194.

9. Drzewiecki D., 2015, Bezpieczeństwo obszarów nadbrzeżnych w południowej części basenu morza bałtyckiego w oparciu o najnowszy raport IPCC (AR5), Przegląd Geopolityczny tom XII, Częstochowa 2015, s. 8 - 33. ISSN 2080-8836 (print) 2392067X (online) Ogólnodostępna wersja elektroniczna: http://przeglad.org/wp-content/ uploads/2015/06/Drzewiecki_Dariusz_PG_tom_12.pdf

10. Drzewiecki D., 2015, Meteorological elements of selected historical events based on the weather map digital reconstruction, Security and Defence, Central European Forum on Military Education, National Defence Uniwersity (Akademia Obrony Narodowej), Quarterly No 4, Warszawa 2015, s. 49-57

11. German Advisory Council on Global Change (WBGU), 2007 - "Climate Change as a Security Risk", Berlin, Germany

12. Graniczny M., Mizerski W., 2009, Katastrofy przyrodnicze, Wydawnictwo Naukowe PWN, Warszawa.

13. Heede Richard, 2013 - “Tracing anthropogenic carbon dioxide and methane emissions to fossil fuel and cement producers, 1854-2010", Climatic Change (2014), Article is published with open access at Springerlink.com. 
14. IPCC, 2014 - Special Report on Renewable Energy Sources and Climate Change Mitigation (SRREN) "Special Report of the Intergovernmental Panel on Climate Change", Cambridge University Press, UK and New York, NY, USA.

15. Janiszewski F., 1988 - Instrukcja dla stacji meteorologicznych, Instytut Meteorologii i Gospodarki Wodnej, Wydawnictwa Geologiczne, Warszawa, s. 66-69.

16. Jaworski B.M., Dietłaf A.A., 1966 - Fizyka, poradnik encyklopedyczny, PWN, Warszawa.

17. Jafernik H., Wilczek Z., Ziarko J., 2000, Meteorologiczna osłona działań lotnictwa. Dom wydawniczy Bellona, Warszawa

18. J. D. Macdougall, 2004 - "Frozen Earth: The Once and Future Story of Ice Ages" University of California Press, Ltd

19. KluczeFM12-XIIExt.SYNOP, DO SZYFROWANIA WYNIKÓW PRZYZIEMNYCH OBSERWACJI METEOROLOGICZNYCH, dla celów synoptycznych, oraz KLUCZE STORM - AVIO, Warszawa 1996.

20. Lorenc H., 2005, Wiatr w Polsce jako element zagrożenia. Instytut Meteorologii i Gospodarki Wodnej.

21. Moran J., Morgan M., 1989, Meteorology the atmosphere and the science of weather. MPC New York.

22. Ostrowski M., 1999, Meteorologia dla lotnictwa sportowego. Aeroklub Polski. Warszawa

23. The CNA Corporation, 2007 - "National Security and the Threat of Climate Change", Alexandria, Virginia, USA.

24. Wpływ zmian klimatu na środowisko, gospodarkę i społeczeństwo (zmiany, skutki i sposoby ich ograniczania, wnioski dla nauki, praktyki inżynierskiej i planowania gospodarczego), tom 3, Klęski żywiołowe a bezpieczeństwo wewnętrzne kraju, Instytut Meteorologii i Gospodarki Wodnej, 2012.

25. Zagrożenia okresowe występujące w Polsce, Rządowe Centrum Bezpieczeństwa RCB - Warszawa, 2013. 